\title{
The Once and Future King: Robert F. Kennedy as a Liberal Icon
}

\section{Anne Mørk}

University of Southern Denmark

\begin{abstract}
This article examines Robert F. Kennedy's status as an icon to the American public and both liberals and conservatives. The difficulty in categorizing Kennedy's complex political beliefs within just one of many liberal traditions is key to understanding his popularity with various - and often opposing-groups within American politics. Whereas conservatives favor Kennedy's tough attitude on law-and-order, liberals admire Kennedy's electoral appeal and ability to unite voters. However, the American people have adopted Kennedy as a non-partisan icon in the tradition of Abraham Lincoln, Martin Luther King Jr., and John F. Kennedy. Starting with Kennedy's death, the American people remembered him as a martyr of American democracy, justice, and equality. In the new millennium, Kennedy has frequently been presented in the media and political rhetoric as tough, but compassionate, and thereby as a liberal icon for the ages.
\end{abstract}

Keywords: Robert F. Kennedy-liberalism-conservatism-presidential electionsassassination-John F. Kennedy-Democratic Party

\section{Introduction}

In his lifetime, Robert F. Kennedy was an immensely controversial figure, either deeply resented or passionately admired by voters, scholars, journalists, and fellow politicians alike. After his assassination in June 1968, his popularity skyrocketed and the critical voices lessened, although they did 
not disappear. The critical voices, mostly right-wing in affiliation, focused on Kennedy's personal ruthlessness, his total dedication to his brother John's political career, and his involvement with the less than admirable aspects of post-WWII politics (his brief career in the McCarthy Committee). ${ }^{1}$ In an Esquire article in November 1968, Malcolm Muggeridge argued that "within twenty-four hours of his assassination he was fully equipped with a halo, a hagiography and all the other trappings of martyrdom in preparation for Instant Canonization."2 Muggeridge also argued that Kennedy would be quickly forgotten due to the instant change in image. As this article will show, Muggeridge was correct in his first assumption, wrong in the second. Kennedy as a martyred icon has remained a constant presence in American political discourse. After his death, friends, aides, and journalists published widely about Kennedy's growth as a man and a politician after John F. Kennedy's death. His death was portrayed as significant loss for the American nation and the political system. ${ }^{3}$ This image of Kennedy has survived. While he is primarily remembered as an icon of conciliation, politicians continue to incorporate their own values and goals into his legacy. Thus, he serves as an icon to both conservatives (classic liberals) and contemporary liberals (modern liberals).

This article explores the legacy of Robert F. Kennedy and how he has become one of the primary liberal icons of the post-1968 era. For this purpose, both political and popular sources will be examined. The difficulty in defining liberalism in an American context as well as placing Kennedy exactly within one version of liberalism has made it possible for politicians and commentators to use Kennedy for their own purposes. Despite conservative admiration for Kennedy, he is frequently mentioned as the quintessential modern liberal, a representative for the social equality sought by many Democratic candidates. ${ }^{4}$ Others, e.g. Bill Clinton, have focused on

1 Examples are Victor Lasky, Robert Kennedy: The Myth and the Man (New York: Trident Press, 1968) and William V. Shannon, The Heir Apparent: Robert Kennedy and the Struggle for Power (New York: The Macmillan Company, 1967).

2 Malcolm Muggeridge, "The Elevation of Senator Robert F. Kennedy”, Esquire, November 1968, p. 167. Robert F. Kennedy Papers, John F. Kennedy Presidential Library and Museum, 1968 Presidential Campaign, National Headquarters Files, Press Division, Box 7.

3 Examples are Edwin O. Guthman, We Band of Brothers: A Memoir of Robert F. Kennedy (New York: Harper and Row, 1971) and Jack Newfield, RFK: A Memoir (New York: Thunder Mouth's Press/Nation Books, 2003).

4 See William Kristol, "In 2008 It's Ronald Reagan vs. Bobby Kennedy”, Time, March 29, 2007, [Online]. http://www.time.com/time/nation/article/0,8599,1604561,00.html. 
Kennedy's ability to combine conservative and liberal elements. Rather than assuming Kennedy is a specific kind of liberal (classic or modern), the argument here is that Kennedy can be fully employed as an icon for the various strands of liberalism due to the complexity and changing nature of his own political thoughts and action. Therefore, this article will explore Kennedy's legacy as both a partisan and non-partisan icon, and how political actors on both sides of the aisle have claimed Robert Kennedy as their own. The public response to Kennedy's death will also be analyzed. In order to examine Kennedy's popularity with different liberals, three different kinds of liberalism are identified-classical liberalism, modern liberalism, and liberalism as a political philosophy. In a contemporary context, this last interpretation of liberalism has included a humanitarian, non-partisan dimension, as exemplified by Martin Luther King Jr. and Abraham Lincoln. It is especially this non-partisan status that Robert Kennedy has assumed more than four decades after his death.

\section{American liberalism}

The definition of liberalism in an American context is a complex one as various groups use their own specific definitions of the term to suit their own purposes. Liberalism in a broad sense can be defined as a philosophy or attitude that advocates individual liberty, pluralism, and compromise based on rational debate. Initially inspired by European thinkers (especially John Locke), American liberal philosophy developed specific characteristics which underlie all political debate. ${ }^{5}$ In The American Political Tradition, Richard Hofstadter argued that

the sanctity of private property, the right of the individual to dispose of and invest it, the value of opportunity, and the natural evolution of self-interest and self-assertion [...] have been staple tenets of the central faith in American political ideologies. ${ }^{6}$

Over the centuries, classical and modern liberalism have developed as two different versions of the liberal philosophy. The two fundamentally agree

5 The idea of Lockean liberalism defining American political ideology was presented in Louis Hartz' 1955 book The Liberal Tradition in America (Harcourt, Brace and World, 1955) which has since been under frequent attacks for being too consensus-driven and neglecting struggles of race and gender.

6 Richard Hofstadter, The American Political Tradition (London: Jonathan Cape, 1971), p. xvi. 
that the individual is the cornerstone of society, but they disagree on how government should protect the individual. Classical liberals (or conservatives) believe in small government-particularly strengthening local and state government rather than federal government-and laissez faire economics. This is a continuation of John Locke's rights-based theory in which the individual stands above the common good. Modern liberalism (or liberals in the current debate) believes in the federal government to outbalance forces such as capitalism or an oppressive majority that might threaten individual liberty. Republicans are considered to be proponents of the classical liberalism and Democrats of modern liberalism although these distinctions do not apply to every member of those parties. According to Cheryl Greenburg, the Civil War was the first conflict in which government was forced to intervene to protect one individual right (the liberty of the slaves) from another rightin this case, the property rights of Southern slave owners. ${ }^{7}$ In the Progressive Era, the development of liberalism was heavily influenced by popular and political demands for government protection for the average citizen from the power of corporations. ${ }^{8}$ However, it was in the New Deal era of the 1930 s that the current distinction between conservatives and liberals arose from the discussion on the nature and scope of the American welfare state. ${ }^{9}$

In his 1959 article "The Coming Shape of American Politics" in The Progressive, liberal historian Arthur M. Schlesinger Jr. presented a new distinction within the liberal framework: qualitative and quantitative liberalism. The fundamental, quantitative needs of the citizens (food, shelter, physical safety) were provided by the government, yet liberals felt the liberal solution lacking in national purpose. As a result, post-war liberals considered qualitative issues to be next on the national agenda. Later, Schlesinger listed issues such as "civil rights, civil liberties, education, the humanization of our cities, the relationship between life and environment, the state of the arts" as matters of qualitative liberalism.

Since the late 1960s, Republicans have successfully portrayed modern liberals as weak in matters of national security, being soft on crime, and a

7 Cheryl Greenburg, "Liberalism," Encyclopedia of American Studies, ed. Miles Orvell (Baltimore: Johns Hopkins Univeristy Press, 2010), p. 1. [Online]. http://eas-ref.press.jhu.edu.proxy1-bib.sdu.dk:2048/view? aid $=530 \&$ from $=$ search \&query=liberalism \&link=search $\% 3$ Freturn $\% 3 \mathrm{D} 1 \% 26$ query $\% 3 \mathrm{Dliberalism} \% 26 \mathrm{sec}$ tion\%3Ddocument\%26doctype\%3Dall

8 Ibid

9 Theodore J. Lowi, The End of Liberalism: Ideology, Policy and the Crisis of Public Authority (New York: W.W. Norton and Co., 1969), pp. 55-56. 
threat to traditional family values. Despite the many scandals involving the Kennedy family, ${ }^{10}$ John and Robert Kennedy have continued to hold a special place in the American imagination. ${ }^{11}$ Bernard von Bothmer argued that they largely escaped the conservative backlash against liberalism that occurred after 1968. John and Robert seemed immune to the criticism due to their continued popularity with the American public. ${ }^{12}$ In von Bothmer's approach, the decade is interpreted according to its political consequences and two competing political interpretations of the 1960s exist. Beginning in the early 1980 s, conservatives (primarily Ronald Reagan) managed to portray the 1960s as an era of social and moral decline. The Bad Sixties included urban riots, anti-war protests, drugs, social unrest, and moral decline. Lyndon Johnson, Richard Nixon, and George McGovern were associated with this interpretation. In contrast, the Good Sixties included a strong stand on foreign policy, a peaceful civil rights movement, and traditional moral values. ${ }^{13}$ John and Robert Kennedy were the primary representatives of this era. The legacy of the Kennedy administration was controlled progress, such as the Peace Corps and the non-violent civil rights movement. ${ }^{14}$ If John F. Kennedy's legacy escaped association with the Bad Sixties due to the assassination, Robert Kennedy's legacy was saved by his anti-crime stance (as Attorney General) and his outspoken criticism of the big government solutions of the Great Society. ${ }^{15}$ That both John and especially Robert had been unpopular with the liberal wing of the Democratic Party at the time made them even more appealing to conservatives. ${ }^{16}$ The division into the Good Sixties and Bad Sixties is crucial for the understanding of Kennedys' appeal to conservatives.

The New Democrats, a movement within the Democratic Party, arose in the mid-1980s as a reaction to electoral failure of modern liberalism. One

10 The American media's preoccupation with the Kennedy family turned from glorification in the 1960s to scandalous disclosures in the 1970s. Rumors of extramarital sex, drug use, and mafia connections tainted the legacy of the Kennedy men (both JFK, RFK, and their father, Joe Kennedy). Despite its publication two decades after the height of the anti-Kennedy reaction, the most powerful account of the Kennedy scandals remains Seymour M. Hersh's The Dark Side of Camelot (Boston: Little, Brown, and Company, 1997).

11 Frequent polls on the legacy of US presidents often place John Kennedy within the top 10 when the polls are conducted among the public. Historians tend to be more sceptical.

12 Bernard von Bothmer, Framing the Sixties: The Use and Abuse of a Decade from Ronald Reagan to George W. Bush (Amherst and Boston: University of Massachusetts Press, 2010), p. 45.

13 Ibid., p. 2.

14 Ibid., pp. 221-222

15 Ibid., pp. 149-154

16 Ibid., pp. 14-15. 
of their leaders was Arkansas Governor Bill Clinton. While they held on to the central role of the federal government, they also criticized the expansion of the welfare state and the lack of communal and personal responsibility. One of the heroes of the New Democrats, as we shall see later in this article, was Robert F. Kennedy.

\section{The life of Robert F. Kennedy}

That Robert Kennedy would become an icon for both liberals and conservatives was not obvious in his lifetime. In fact, he was vastly unpopular on both sides of the aisle. Kennedy himself stated during his career in the Senate in the mid-1960s, "I'm the only candidate who has ever united business, labor, liberals, Southerners, bosses, and intellectuals. They're all against me." ${ }^{17}$ His career in the political world took off in the early 1950 s, working as legal counsel, first for Senator Joseph McCarthy and later for the McClellan committee which targeted corrupt union leaders. Primarily interested in law and order, with a black and white world view and a ruthless demeanor that earned him the nickname "Bad Bobby", Kennedy was widely unpopular with intellectuals, liberals, and the majority of the Democratic Party. ${ }^{18}$ Named Attorney General in 1961 by President Kennedy, Robert's years in the Justice Department combined his newfound liberal sensibility and his conservative standpoints. His methods in the war on organized crime-particularly the lack of respect for civil libertieswere deeply resented by the liberal members of the Democratic Party. Southern Democrats and Republicans resented him even more when he sided with African Americans in their struggle to end segregation. Yet, it was his brother's death in November 1963 that would redefine his political role. His image as a ruthless opportunist was moderated by his newfound vulnerability and personal grief over his brother's death. As Senator from New York, he was able to liberate himself from his brother's legacy and created his own identity as champion of the weakest citizens. Kennedy would transcend the traditional classic versus modern liberal dichotomy by combining quantitative beliefs in government's responsibility to provide for the fundamental needs of its citizens with qualitative beliefs in the dignity of the individual, community, and the empowerment of the 
people beyond the government. Kennedy's message appealed to the white working class, Hispanics, and African Americans-an unlikely coalitionin the 1968 election. However, he remained unpopular within both parties: Republicans disliked his advocacy for racial equality and his rhetoric of social change. Democrats distrusted his rivalry with President Lyndon B. Johnson, and many liberals were unable to forgive his six months of working for Joseph McCarthy.

\section{The assassination of Robert F. Kennedy}

In March 1968, Kennedy announced his candidacy for President. Competing with liberal favorite Eugene McCarthy and Vice-President Hubert Humphrey, he campaigned to end the war abroad and unite Americans at home. After the death of Martin Luther King Jr. in April of that year, Kennedy had emerged as many Americans' best hope for social and racial equality. ${ }^{19}$ However, his candidacy ended when he was shot after winning the California primary. He was still fighting for his life in a Los Angeles hospital when his transformation from fallible politician to glorified martyr and icon began. Particularly, the press played a significant role in portraying his death as a symbolic act that would have profound influence on American life. In New York, a local tv-station aired the word SHAME for two and a half hours. ${ }^{20}$ Many of the editorials and articles from major newspapers immediately after his death focused on his appeal to the poor and minorities, his ability to inspire hope and his complex personality (many of them mentioned that he was not as ruthless as often claimed). ${ }^{21}$ However, few mentioned his specific policy initiatives or President John F. Kennedy. By his death, Robert Kennedy had been able to create a political legacy independent of his brother, even if it was not necessarily based on specific political achievements. Washington Post's Richard Harwood correctly predicted that "the old illusions of Robert Francis Kennedy have probably died with him-llusions of ruthlessness, coldness and cant. And new illusions,

19 Jack Newfield, RFK: A Memoir (New York: Thunder's Mouth Press/Nation Books, 2003), pp. $250-251$.

20 Assassination: Robert F. Kennedy 1925-1968, editors of United Press International and Cowles (New York: Cowles, 1968), p. 65.

21 A collection of editorials and articles about Kennedy's death and funeral, in both American and international publications, are available in Pierre Salinger et. al., An Honorable Profession: A Tribute to Robert F. Kennedy (New York: Doubleday, 1993). 
as in the case of his dead brother John, may soon take their place-largerthan-life illusions of grandeur and gallantry."22

Most articles immediately after the assassination were generally positive - a significant shift from the anti-Robert Kennedy articles and literature that dominated much of the debate about him in 1968. ${ }^{23}$ Jack Newfield-who had followed Kennedy on the campaign trail—wrote a very positive piece in The Village Voice in which he noted, "if I had written these things two weeks ago, The Voice would have been deluged with letters calling me a whore. Now such anecdotes fill the papers and the networks, and no one doubts them." ${ }^{24}$ Also in Congress, Kennedy was honored by enemies as well as allies-even his political opponents recognized his support for the average citizen and compassion for the weakest in society, as well as public service and patriotism..$^{25}$

Kennedy's funeral and particularly the train ride from New York (the service was held at St. Patrick's Cathedral) to Washington, D.C. (Kennedy was buried at Arlington National Cemetery) has become part of the Kennedy legend. Along the tracks, thousands of mourners waited to see the train pass. People of all ages, races, and social strata paid their last respect to Kennedy in what was called "an unbroken chain of sadness." ${ }^{26}$ The turnout at the train route signified the degree to which Kennedy had moved the public spirit. Economist J.K. Galbraith noted, "if you were burying Ronald Reagan, you would obviously want to do it with an airplane; but if you are going to bury Robert Kennedy, his people live along the tracks." ${ }^{27}$ Already at the time of the funeral, the media paid attention to the political connotations of the train ride. United Press International noted that the funeral train passed through many of the same towns as Lincoln's in $1865 .^{28}$ The funeral

22 Harwood, Richard in Washington Post, June 8, 1968 in Salinger et. al. p. 85.

23 See Jerome Agel, "A Flood of Words on RFK", New York Daily, June 7, 1968. RFK Papers, JFK Presidential Library and Museum, 1968 Presidential Campaign, National Headquarters Files, Press Division, Box 7.

24 Jack Newfield in The Village Voice, June 13, 1968 in Salinger et. al. p. 67.

25 Memorial Services in the Congress of the United States and tributes in eulogy of Robert Francis Kennedy Late a Senator from the state of New York (Washington, D.C.: United States Government Printing Office, 1968).

26 Robert Kennedy Remembered. Directed by Charles Guggenheim. [DVD]. Guggenheim Productions Inc., 1968.

27 John Kenneth Galbraith quoted in George Plimpton and Jean Stein, eds, American Journey: The Times of Robert Kennedy (London: Andre Deutsch, 1971), p. 32.

28 Assassination p. 207. 
procession stopped at three locations in Washington, D.C. that had been significant in Kennedy's career-the Senate building, the Justice Department, and the Lincoln Memorial.

Kennedy's death hit minorities and the poor particularly hard. In a poll in July 1968, 92\% of residents in Harlem said that Robert's death affected them as much or more than John F. Kennedy's death. ${ }^{29}$ At San Quentin State Prison, Native American prisoners performed a mourning dance rite as a tribute. ${ }^{30}$ The frustration and pain of many Native Americans are summed up in a letter from a Native American woman to Kennedy's widow immediately after his death. She wrote, "some who had never voted before were going to ... to vote for Bobby. We felt hope for 'our country' ... What we feel now is despair." ${ }^{1}$

A year after his death, Kennedy's new image had been fundamentally transformed in the public mind. A Time article on the first anniversary of his death noted,

Bobby Kennedy has undergone a considerable transformation in the American memory and conscience. Few today recall Kennedy as the abrasive prosecutor, aggressive politician, and outspoken advocate. The reputation that lingers is one he went far toward creating during the last few months of his life: war critic, champion of the black and the Mexican-American, crusader for the very young, the very old, and all those who have been shunted aside from social and economic progress. ${ }^{32}$

In many accounts of the late 1960 s, the assassination of Kennedy is mentioned alongside the assassination of King and the demonstrations against the Vietnam War as a sign that American society was falling apart. However, there seemed to have been particular significance to Robert Kennedy's death. The implication is that America could recover from John Kennedy's death or King's, but not Robert's. Already at the time of the assassination, there was a feeling that Kennedy's death marked the end of an era, and that the last hope for the poor had died. Pete Hamill commented in Good Housekeeping, "as that train came into Baltimore, and we saw black faces, like a

29 Newfield 2003, p. 74.

30 "American Indian Cultural Group at California State Prison", San Quentin, California, June 6, 1968 in Salinger et. al. p. 173.

31 "Letter from Mrs. Gertrude Chaflin to Mrs. Robert F. Kennedy", June 6, 1968 in Salinger et. al. p. 76.

32 "Anniversaries: RFK Remembered", Time, June 6, 1969, [Online]. http://www.time.com/time/ magazine/ article/0,9171,941663,00.html 
sea tide, covering every surface, young and old and wary and disfranchised, carrying candles, singing about how 'His Truth goes searching on' yet asking 'Why, God, why?' I knew that my loss was minor-the country's loss might never be added up completely." 33 In a news report on the assassination, Walter Cronkite stated, "the people weep for the Kennedys. Perhaps they should weep, too, for themselves." ${ }^{4}$

\section{Robert F. Kennedy as a non-partisan icon}

Popular memorials and tributes tend to focus on Kennedy's image as a conciliatory leader, not as a partisan politician. Furthermore, few mention his work as Attorney General or his efforts as legal counsel for the McCarthy and McClellan committees. His ideological complexity combined with his strict moral values make him appealing to both the left and the right. Despite Kennedy having been used for political purposes by both parties, the image that Kennedy has assumed with the wider public appears to be one of non-partisan leadership. At a memorial mass on the 25th anniversary of Kennedy's death in 1993 — an event attended by 18,000 people-President Bill Clinton said,

He saw the world not in terms of right and left but right and wrong. And he taught us lessons that cannot be labeled except as powerful proof. Robert Kennedy reminded us that on any day, in any place, at any time, racism is wrong, exploitation is wrong, violence is wrong, anything that denies the simple humanity and potential of any man or woman is wrong. ${ }^{35}$

\section{When speaking at the Robert F. Kennedy Human Rights Award Ceremony} in November 2009, President Barack Obama stated,

Bobby's legacy wasn't a devotion to one particular cause or a faith in a certain ideology, but rather, it was a sensibility. A belief that in this world there is right and there is wrong, and it is our job to build our laws and our lives around recognizing the difference. ${ }^{36}$

An important aspect of his non-partisan legacy is his ability to inspire others. At the celebration of what would have been Kennedy's 80th birthday,

33 Pete Hamill in Good Housekeeping, September 1968 in Salinger, Pierre et. al. p. 43.

34 “CBS News Special Report”, June 1968. [Online]. hhtp://www.cbsnews.com/video/watch/ ?id=4156677n.

35 William J. Clinton, "Remarks at the Memorial Mass for Robert F. Kennedy in Arlington Virginia," The American Presidency Project, June 6, 1993. [Online]. http://www.presidency. ucsb.edu/ws/?pid=46662.

36 Barack Obama , "Remarks at the Robert F. Kennedy Human Rights Awards Ceremony," The American Presidency Project, November 23, 2009. [Online]. http://www.presidency.ucsb.edu/ws/ ?pid=86927. 
various speakers stated that Kennedy had inspired them to go into public service and that he gave people of all political convictions the belief in the ability of the individual to change history. Among those who claimed that they had been inspired by Kennedy were politicians of opposing views, such as conservative commentator Joe Scarborough and liberal Democratic Congressman Dennis Kucinich. ${ }^{37}$

The difficulties of categorizing Kennedy ideologically in his lifetime proved to be an advantage to his legacy. Not only does it make him attractive to both liberals and conservatives, but also to an American public famously distrustful of ideology. Thus, Kennedy's legacy is one that appeals not only to traditional or modern liberalism, but to the fundamentals of American liberal philosophy, such as individualism and progress.

In the public imagination, Kennedy is often associated with other slain national leaders, such as Abraham Lincoln, John F. Kennedy, and Dr. Martin Luther King Jr. The man who was rumoured to be a ruthless opportunist during his lifetime is celebrated today as a leader of conciliation, change, and hope. Despite the troubled relationship during their lifetime, Kennedy and King are frequently mentioned in the same sentence as leaders on similar issues. ${ }^{38}$ In 1978, Kennedy was posthumously awarded the Congressional Gold Medal of Honor. ${ }^{39}$ That same year it was decided to print commemorative stamps picturing Kennedy and King, signifying their shared legacy. ${ }^{40}$ Another example is the 1968 song Abraham, Martin and John, first sung by Dion. The verse dedicated to Kennedy goes,

Anybody here seen my old friend Bobby?

Can you tell me where he's gone?

I thought I saw him walkin' up over the hill

With Abraham, Martin and John ${ }^{41}$

37 "Robert F. Kennedy Tribute", American Perspectives. C-SPAN. November 16, 2005. [Online]. hhtp:// www.c-spanvideo.rog/program/189979-1.

38 Kennedy's relationship with King during the Kennedy administration is chronicled in Arthur M. Schlesinger's Robert Kennedy and His Times (New York: Ballantine Books, 1978). pp. 343-367. Joseph A. Palermo has an excellent chapter on the Kennedy-King relationship after John F. Kennedy's death. See Palermo. In His Own Right: The Political Odyssey of Senator Robert F. Kennedy (New York: Columbia University Press, 2001).

39 http://www.senate.gov/reference/resources/pdf/RL30076.pdf.

40 The Washington Post, December 10, 1978. [Online]. http://www.lexisnexis.com.proxy1-bib.sdu.dk:2048/ hottopics/lnacademic/?

41 Richard Holler, "Abraham, Martin and John." [Online]. http://www.jfklibrary.org/Historical+ Resources/ Archives/Reference+Desk/Abraham+Martin+and+John.htm. 
He is categorized alongside Lincoln, Dr. King and John F. Kennedy as the liberal leaders who wished to unite all Americans, but paid the ultimate price for their message stating, "he freed lotta [sic] people but it seems the good they die young." 42

Yet another example is The Landmark for Peace Memorial in Indianapolis at the site of Kennedy's famous speech after the King assassination. The memorial shows Kennedy and King reaching their hands out to one another. This gesture symbolizes their importance in the unification of conflicting groups and races; however, the distance between the two symbolizes that the struggle is not over yet.

Frequently commentators or politicians will mention that the issues relevant for America today are the same as in 1968 that Kennedy's solutions to those problems are still valid, and that his death changed American politics forever. ${ }^{43}$ It is especially on the anniversary of Kennedy's death that these articles appear. Thus, Kennedy turns from icon to prophet. When Barack Obama was elected in 2008, many commentators brought attention to a 1961 interview in which Kennedy predicted that a black person could be elected president in 40 years. ${ }^{44}$

Thus, Kennedy today is viewed in popular culture more as a humanitarian leader than as a partisan politician. Also, in politics, his views on qualitative issues are quoted more often than his views on economic issues, illustrating the non-partisan appeal of his qualitative message. It is not a coincidence that the Robert F. Kennedy Memorial Foundation was renamed the Robert F. Kennedy Center for Justice and Human Rights. ${ }^{45}$ The 2006 film Bobby served as a powerful indicator for the non-partisan icon Kennedy has become. ${ }^{46}$ The film, which focuses on mostly fictional characters at the Ambassador Hotel the night of the assassination, presents Kennedy as an icon of social justice, racial equality, and non-violence. Kennedy is absent for most of the film, though mentioned frequently in conversations in scenes focusing on Latino bus boy Jose (based on real life Juan Romero, played by

42 Ibid.

43 Examples are Peter S. Canellos, "Troubles that US faces today were on RFK's mind in '68," The Boston Globe, June 5, 2008, and Evan Thomas, "RFK's Last Campaign”, Newsweek, August 6, 1998. p. 46.

44 Karen Hatter, "Robert F. Kennedy Predicted a Black President in 1961," November 6 2008. [Online]. http:// www.nowpublic.com/world/robert-f-kennedy-predicted-black-president-1961.

45 Robert F. Kennedy Center for Justice and Human Rights. [Online]. http://www.rfkcenter. org/about/organization.

46 Bobby. Directed by Emilio Estevez. [DVD]. The Weinstein Company and Bold Films, 2006. 
Freddie Rodriguez) and African American campaign worker Dwayne Clark (played by Nick Cannon). Thus, Kennedy's impact is shown to be primarily on minorities. In one scene, Dwayne says that Kennedy is the only hope after the death of Dr. King. Furthermore, when Kennedy is assassinated in the hotel kitchen the other (white) characters react by focusing on their own wounds or those of friends and family-in comparison, Jose holds the wounded Senator Kennedy's hand, while Dwayne reacts with anger and frustration. There is a certain distance between Kennedy's death and the white characters, but Dwayne and Jose feel Kennedy's pain themselves. Finally, in the last scenes of the film-portraying the chaos after the shooting-Kennedy's famous "Mindless Menace of Violence" speech (which he gave the day the after the death of Dr. King) is heard.

In November 2008, the Triborough Bridge in New York City was renamed the Robert F. Kennedy Bridge. ${ }^{47}$ The dedication was the result of years of advocacy from the Kennedy family. Besides the symbolic significance of renaming that particular bridge-it connects Manhattan, Queens, and the Bronx and thereby reflects Kennedy's role as conciliator-the dedication was an important part of the Kennedy family's attempts to secure his legacy. However, New York historian Kenneth Jackson opposed the renaming due to the carpetbagger issue_- "he certainly was an important person in American history, just not an important person in New York history." ${ }^{48}$ Jeremy Olshan from New York Magazine also opposed it, but because "there is no reason to think Kennedy, an environmentalist before his time, would have wanted his name associated with the notorious bottleneck site." ${ }^{49}$

\section{Robert F. Kennedy as icon to Republicans}

Although Kennedy did not become a favorite of the Republicans until 2001, President Ronald Reagan knew the advantages of quoting Kennedy already

47 Examples of other dedications are the Robert F. Kennedy Justice Department Building, the RFK Memorial Stadium in Washington, D.C. and the Robert F. Kennedy Community Schools in Los Angeles, an education complex for the areas' mostly poor, Hispanic children located at the site of the now-demolished Ambassador Hotel where Kennedy was shot.

48 Jacob Gershman, “Enduring Wish May Come True in RFK Bridge,” New York Sun, January 2008. [Online]. http://www.nysun.com/new-york/enduring-wish-may-come-true-in-rfk-bridge/ 69058/.

49 My emphasis. Jeremy Olshan, "The Irony of Naming the Triborough Bridge after RFK," New York Magazine, November 14, 2008. [Online]. http://nymag.com/daily/intel/2008/11/the_irony_of_naming_the_tribor.html. 
in the 1980s. Many working-class whites, who had supported Kennedy in 1968, now voted Republican (the Reagan Democrats). Knowing that Kennedy was still popular within those communities, he was a Democrat that Reagan could afford to quote. In 1987, Reagan would quote Kennedy's statement from his 1964 book The Pursuit of Justice, "progress is a nice word, but change is its motivator and change has enemies" when arguing for a deficit reduction..$^{50}$

To this day, conservatives admire Kennedy's efforts as Attorney General due to his determined struggle against crime and corruption. One example of a conservative admirer of Kennedy is commentator Bill O'Reilly who compared recent Attorney Generals to the quintessential man in the position-Kennedy himself. On a conservative website, O'Reilly stated, "the attorney general of the United States is supposed to be a crime fighter and a corruption buster. RFK knew that and did that." ${ }^{11}$ On CNBC News, he further argued,

There was something about Kennedy, when he saw this injustice out there, when he saw the people being taken advantage of, he wanted to right the wrong. That's what all politicians should have, and that's what all journalists should have. See, we have something in common with politicians; we're here. We're given power by the Constitution to right wrongs, to look out for the folks. Well, how many of us do that? How many politicians do that? That's why I admire RFK. ${ }^{52}$

O'Reilly also admires Kennedy's efforts for civil rights, one of the few conservatives to do so. He argued that Kennedy's tough actions on law and order and civil rights "make Kennedy not only a Patriot but a true American hero." ${ }^{33}$ Kennedy as a law and order advocate also served as a hero to former New York Mayor Rudolph Giuliani. In a 2007 interview, Giuliani recalled how he as a child watched Kennedy's televised interrogation of

50 Ronald Reagan, "Remarks at the White House Briefing for Members of the Deficit Reduction Coalition," The American Presidency Project, July 10, 1987. [Online]. http://www.presidency. ucsb.edu/ ws/?pid=34533.

51 Bill O'Reilly, ”The Attorney General Blues," October 21, 2002. [Online]. http://www.wnd.com/ index. php?pageId $=15751$.

52 "Bill O'Reilly of 'The O'Reilly Factor' on the war on terrorism, anthrax attacks on the US, his book "The No Spin Zone, and government takeover of airport security," CNBC News Transcript, October 27, 2001. [Online]. http://www.lexisnexis.com.proxy1-bib.sdu.dk:2048/hottopics/ lnacademic/?

53 Bill O'Reilly, Pinheads and Patriots: Where You Stand in the Age of Obama (New York: William Morrow, 2010), p. 154. 
corrupt union leader Jimmy Hoffa. Later, Giuliani himself would prosecute the Teamsters Union, and, like Kennedy, would pay the price in public disdain. ${ }^{54}$ After 9/11, Giuliani's speech to New York drew national attention for a powerful message and rhetoric, and it was compared with Kennedy's speech after King's assassination, presenting Giuliani as a political healer in the Kennedy tradition. ${ }^{55}$ For an untraditional Republican as Giuliani, Kennedy was a icon of both conservative toughness and liberal healing.

Kennedy's legacy of moral values independent of ideology was also used by the Bush administration after 9/11. President Bush and Attorney General John Ashcroft attempted to draw a moral parallel between organized crime and the War on Terror. Ashcroft used Kennedy's legacy to legitimize an infringement of civil liberties, claiming that Kennedy had done the same thing as Attorney General, arguing, "Attorney General Kennedy made no apologies for using all of the available resources in the law to disrupt and dismantle organized crime networks." 56 However, Kennedy's daughter, Kerry Kennedy Cuomo publicly criticized Bush and Ashcroft's mention of her father and claimed that he never would have approved of the infringement of civil liberties. ${ }^{57}$

Despite being hated by the right wing for his support of civil rights and by the left wing for his disrespect for civil liberties in the war on crime, Kennedy has become the non-partisan hero of the Justice Department. The definitive non-partisan approval of Kennedy was the dedication of the Robert F. Kennedy Department of Justice Building in November 2001. At the dedication, President Bush referred to him as "a good and decent man" and stated, "America today is passing through a time of incredible testing. And as we do so, we admire even more the spirit of Robert Kennedy, a spirit that tolerates no injustice and fears no evil. That's how this country sees him." 58

54 David Weigel, “The Liberal Candidate”. Reason Vol. 39, No. 7, December 2007, pp. 24-33. [Online]. http:// reason.com/archives/2007/11/14/the-liberal-candidate.

55 Ibid.

56 John Ashcroft, "Prepared Remarks for the US Mayors Conference," October 25, 2001. [Online]. http:// www.justice.gov/archive/ag/speeches/2001/agcrisisremarks10_25.htm.

57 Jake Tapper, “A Kennedy the Bush administration can love," Salon, November 21, 2001. [Online]. http:// www.salon.com/news/politics/feature/2001/11/21/rfk/index.html.

58 George W. Bush, "Remarks on the Dedication of the Robert F. Kennedy Department of Justice Building," The American Presidency Project, November 20, 2001. [Online]. http://www.presidency. ucsb.edu/ ws/?pid=63476. 
It is the Robert Kennedy of the 1950s with a black-and-white, moralistic worldview that appeals to the right wing. When O'Reilly and Ashcroft express their admiration for him as Attorney General, they conveniently overlook his left-wing leadership after $1963 .{ }^{59}$ Particularly his opposition to the Vietnam War is rarely mentioned by his conservative supporters. According to them, his efforts as Attorney General belong in the Good Sixties, whereas his liberal leadership occurred during the Bad Sixties.

Despite Kennedy's popularity among many conservatives, some criticism of Kennedy still appears in conservative forums. However, their main point of criticism was not the man himself, but what they believe to be a misunderstood admiration for Kennedy's views. When the memory of Kennedy was invoked at the funeral of Coretta Scott King in 2006, The Weekly Standard responded by focusing on Kennedy's approval of the wiretapping of Martin Luther King while he was Attorney General. ${ }^{60}$ Conservative sceptics argue that Kennedy was never really as liberal as the left-wing wants him to be or that they overestimated his influence in $1968 .{ }^{61}$ Conservative publications, such as The Weekly Standard, National Review, and American Spectator, are among the most vocal critics of Kennedy's legacy as a liberal icon.

\section{Robert F. Kennedy as icon to Democrats}

The Democratic Party's use of Kennedy's legacy began already at the 1968 National Democratic Convention which proved to be a crucial turning point for the party. Democrats look back at the convention as a scene of sorrow and embarrassment. According to Bill Clinton, the only positive highlight of the convention was a documentary about Kennedy by Charles Guggenheim. ${ }^{62}$ The film provides significant insight into the status that Kennedy came to hold within the party, and the romantic view of him that began to form immediately after his death. The film makes no mention of Joseph

59 Joseph A. Palermo, "Robert Kennedy, Unlikely New Hero of the Rightwing," November 12, 2001. [Online]. http://hnn.us/articles/394.html.

60 “Coretta's Funeral, Merkel and More," The Weekly Standard, Vol. 11, No. 22, February 20, 2006, p. 2. [Online]. http://www.lexisnexis.com.proxy1-bib.sdu.dk:2048/hottopics/lnacademic/ ?sfi=AC00NBGenSrc $\mathrm{h} \& \mathrm{csi}=154608 \& \mathrm{shr}=\mathrm{t}$.

61 John Pilger, “After Bobby Kennedy,” May 29, 2008. [Online]. http://www.newstatesman.com/ north-america/2008/05/obama-pilger-mccain-kennedy.

62 Bill Clinton, My Life (London: Hutchinson, 2004), p. 132. 
McCarthy, Jimmy Hoffa, President Lyndon Johnson, or the split in the party over the Vietnam War. The civil rights aspect of Kennedy's time as Attorney General is emphasized rather than law and order. However, the most significant focus in the film is on his fight for equality and justice, his travels to South America and South Africa, and his speech in Indianapolis on the night of King's death. ${ }^{63} \mathrm{~A}$ few months after his death, the Democrats were already employing the aspects of Kennedy's political life they wished to represent themselves.

At the time of the 20th anniversary of Kennedy's death in 1988, the media and Democratic politicians began to renew their interest in Robert Kennedy as a political leader. The number of articles and editorials in June 1988 about Kennedy exceeds the number published for the 30th anniversary in 1998 and the 40th anniversary in 2008. A poll in Rolling Stone in 1988 placed Robert Kennedy as the second-most admired American (only surpassed by Martin Luther King Jr.) among 18-to-44-year-olds, ${ }^{64}$ signifying to Democrats that he could be used as an instrument in mobilizing voters. 1988 also saw the republication of classic books on Kennedy by Jack Newfield ${ }^{65}$ and Jules Witcover ${ }^{66}$, as well as the release of his campaign speeches ${ }^{67}$ In the article "The Last Hero" in Time, Margaret Carlson suggests that after a decade and a half of public apathy after Watergate and the conservative Reagan administration, many people were once again searching for an idealistic leader. ${ }^{6}$ For this purpose, Robert Kennedy was perfect. Due to his toughness, anti-communism, and focus on law and order, conservatives would not categorize him with "weak" liberals, such as Walter Mondale and Michael Dukakis, yet he represented change, equality, and hope. This image of Kennedy as the ideal tough liberal is still used today. Part of his appeal to Democrats is his legacy of being, what Barack Obama in 2005 called, "at once both hard-headed and big-hearted." ${ }^{69}$ The 1988

\section{Robert Kennedy Remembered.}

64 Margaret Carlson, “Robert Kennedy: The Last Hero,” Time, May 9, 1988. [Online]. http://www.time.com/ time/magazine/article/0,9171,967366,00.html.

65 Jack Newfield, RFK: A Memoir (New York: Thunder Mouth's Press/Nation Books, 2003).

66 Jules Witcover, 85 Days: The Last Campaign of Robert Kennedy (New York: G.P: Putnam's Sons, 1969).

67 Kenneth Reich, "RFK Remembered: L.A. Conference Planned to Revive Spirit of His '68 Campaign", Los Angeles Times, February 5, 1988. Robert F. Kennedy Tributes Collection, RFK Papers, JFK Presidential Library, MS 88-103.

68 Carlson.

69 Barack Obama, "Speech at the Robert F. Kennedy Human Rights Awards Ceremony \& Commemoration of Robert F. Kennedy's 80th Birthday," November 16, 2005. [Online]. http://obamaspeeches.com/039- 
presidential campaign provided the opportunity for a revival of Kennedy's legacy. Scholars, aides, and journalists who had supported Kennedy in 1968 had become disillusioned by the Reagan years and looked to Kennedy to provide a liberal revival. Such an example is the "R.F.K. Remembered" conference at Loyola Maramount University in April 1988. Coordinated by former Kennedy aide Paul Schrade (who was among those shot by Sirhan Sirhan at the Ambassador Hotel), the conference was a meeting of old Kennedy supporters, such as historian Arthur M. Schlesinger Jr., union leader Cesar Chavez, activist Tom Hayden, and journalist Jack Newfield, in an attempt to awaken his political legacy of activism, idealism, and sense of public service. ${ }^{70}$

As the 1992 presidential election approached, Kennedy as an icon became increasingly appealing. Similar to 1968 , the country seemed to be at a crossroads. The country's economic difficulties and racial tensions appeared to be reminiscent of 1968. Many Democrats tried to recapture the belief in change that had defined the early 1960s. As Kennedy had become the symbol of the hope of change in 1968 and his assassination the symbol of its ultimate failure, Kennedy became the primary icon to Democrats. According to Carlson, Kennedy became an icon because "as a memory, he evokes an era of political passion and social commitment that stands in haunting contrast to 1988 . As a myth, he is a vessel into which all dreams can be poured." 71

Bill Clinton quoted both Robert and John Kennedy frequently throughout his presidency. On his way to his inauguration in January 1992, he visited the graves of the Kennedy brothers at Arlington National Cemetery, and the 1992 Democratic Convention featured a video about Robert Kennedy. At the 1996 convention, Clinton mentioned only Robert, but not John. ${ }^{72}$ After the electoral failures of the 1980s, Democrats wanted to be "associated with Democrats who could win." 73 Thus, Democrats themselves were buying into the theory of weak Democrats. In his autobiography, Clinton cites Kennedy as the first New Democrat as,

Robert-F-Kennedy-Human-Rights-Award-Ceremony-Obama-Speech.htm.

70 Program for "R.F.K. Remembered" Conference, Loyola Marymount University, April 23 1988. Robert F.

Kennedy Tributes Collection, MS 88-103.

71 Carlson.

72 von Bothmer p. 151.

73 Brian Dooley, Robert Kennedy: The Final Years (New York: St. Martin's Press, 1996), p. 4. 
he believed in civil rights for all and special privileges for none, in giving poor people a hand up rather than a handout: work was better than welfare. He understood in a visceral way that progressive politics requires the advocacy of both new policies and fundamental values, both far-reaching change and social stability. ${ }^{74}$

Clinton frequently mentioned Kennedy's distrust of big government and bureaucracy in order to give New Democrats a positive, liberal image. In August 1996, he quoted Robert's words on the importance of work to the American character when signing a new welfare reform into law. The incident angered Peter Edelman (an aide to Kennedy during his Senate years) enough to resign his post as assistant secretary of Health and Human Services and inspired a letter to Edelman from Kennedy's daughter, Rory, in which she claimed that Clinton had been "bastardizing, in my opinion, his [Robert's] name and legacy." 75 The Kennedys argued that Clinton had used Robert's words on work to justify cutting welfare spending while ignoring his support for welfare for the weakest and poorest in society. The dispute over the welfare bill signifies the split that occurred in Kennedy's image and legacy in the beginning of the 1990s between Kennedy, the tough liberal, and Kennedy, the compassionate healer. Democrats wished to appeal to those voters who distrusted modern liberalism by focusing on his conservative values while also appealing to those voters who still believed in Kennedy's qualitative vision.

The Democrats also invoked another aspect of Robert's legacy, specifically his role as the last liberal who could appeal to both racial and ethnic minorities and working class whites. The Democrats were no longer the working man's party they had been under Franklin D. Roosevelt and Harry Truman, and Kennedy was the last Democratic leader who had successfully combined quantitative (economic) issues (which appealed to the working class) and qualitative issues (which appealed to the middle class and the intellectuals). As Democrats refused to accept the loss of working class whites to Republicans, Kennedy's 1968 campaign served as the inspiration for Clinton's 1992 presidential campaign. ${ }^{76}$ However, in the late 1990s and

74 Clinton, My Life, p. 122.

75 Peter Edelman, Searching for America's Heart: RFK and the Renewal of Hope (Boston and New York: Houghton Mifflin Company, 2001), pp. 1-6.

76 Ronald Steel, “The Bobby Gap,” New Republic, Vol. 206, Issue 21, May 25, 1992, pp. 16-17. [Online]. http://web.ebscohost.com.proxy1-bib.sdu.dk:2048/ehost/detail?vid=3\&hid=105\&sid= $56 f d 60 b 5-1343-$ 
early 2000s, the left-wing focus on Kennedy seemed to diminish, as Clinton was now able to fulfil the role of a "strong" Democrat.

In a 2007 article in Time, William Kristol argued that the 2008 presidential election would be a symbolic battle between Ronald Reagan and Robert Kennedy, identifying these as the primary icons of the two parties. Kristol claimed that for the Democrats "finishing Bobby's work is the most gripping and compelling task." 77 While Republicans chose to focus on his conservative attitudes, Democrats were trying to turn Kennedy's message of equality and change into the theme of the party once again. The revival of Kennedy's legacy in 2007/2008 coincided with the 40th anniversary of his death. The three major Democratic candidates for the presidencyBarack Obama, Hillary Clinton, and John Edwards-all sought Kennedy's mantle. ${ }^{78}$ Especially Obama's campaign sparked a renewed interest in Kennedy's legacy. Hillary Clinton was told by her campaign strategist Mark Penn about Obama that, "He may be the J.F.K. in this race, but you are the Bobby." 79 Democrats had become hooked on two different kinds of liberal icons-John Kennedy as the cool, well-educated elitist and Robert Kennedy as the radical maverick who was unpopular with the party machine but understood how to mobilize the voters. Democrats in 2007/2008 returned to the Kennedy icon used by the New Democrats in the 1992, as a candidate who headed a new, powerful coalition. The major difference between Obama's use of Kennedy in 2008 and Clinton's use in 1992 was the degree of liberalism in their issues. Whereas Bill Clinton sometimes referred to Kennedy's traditionally liberal attitudes on quantitative issues, such as opposition to welfare solutions and toughness on law and order, Obama focused solely on Kennedy's message of community and conciliation. Obama would combine Kennedy's qualitative message with a quantitative one of modern liberalism, a strategy that New Democrats had not dared to follow. Also, Obama's message of "there is not a liberal America and a conservative America; there is the United States of America" 80 seemed a modern tribute to Kennedy's request for a sense of national community. During his

4a34-b876-3fbd207b28f4\%40sessionmgr114\&bdata=JnNpdGU9ZWhvc3QtbG12ZQ\%3d\%3d\#db=aph\& $\mathrm{AN}=12031497$.

77 Kristol.

78 Leonard C.Robinson, "Chasing the Elusive Ghost of RFK in 2008," July 23, 2007. [Online]. http://hnn.us/ articles/40767.html.

79 David Reminick, The Bridge: The Life and Rise of Barack Obama (New York: Picador, 2010), p. 481.

80 Remnick pp. 398-399. 
campaign, Obama commented on the Virginia Tech massacre by referring to Kennedy's speech on the night of Martin Luther King Jr.'s death, stating that the violence was still a major issue to be addressed. ${ }^{81}$ Thereby, Obama also implied that he was the new Kennedy, a conciliatory leader able to unite conflicting groups and heal the nation's wounds. Obama had previously identified himself with Kennedy. After watching the movie Bobby, Obama reportedly stated that he wanted to create a new coalition similar to Kennedy's. ${ }^{82}$ During his time in the Senate, Obama even used Kennedy's old desk. ${ }^{83}$

Hillary Clinton also attempted to identify herself and her candidacy with Kennedy. She compared her underdog candidacy against Obama, who was leading in the polls, with Robert's race against Vice-President Hubert Humphrey and Senator Eugene McCarthy in 1968. When she was asked to leave the race because of Obama's lead in delegates, she answered that Robert Kennedy had not been assassinated till June.$^{84}$ However, the assassination remaining a sensitive topic for Democrats combined with the fear of the possible attempt on Obama's life made the media accuse Clinton of tastelessly abusing Kennedy's legacy. ${ }^{85}$

The third liberal candidate who invoked Kennedy's legacy in the 2008 election was John Edwards who conducted a "Road to One America Tour" to focus on the issue of poverty. Edwards concluded the tour in Prestonburg, Kentucky - the same place Kennedy had ended his poverty tour through Appalachia in 1968. Edwards did his best to copy Kennedy, even telling an audience, "I want you to join us to end the work Bobby Kennedy started." 86

81 Ruth Conniff, "Obama’s Kennedy Bid,” The Progressive, Vol. 71, Issue 6, June 2007, pp. 14-15. [Online]. http://web.ebscohost.com.proxy1-bib.sdu.dk:2048/ehost/detail?vid=3\&hid=12\&sid= fb901e4f-

9376-42c9-b547-531ac2c0965c\%40sessionmgr4\&bdata=JnNpdGU9ZWhvc3QtbG12ZQ\%

$3 \mathrm{~d} \% 3 \mathrm{~d} \# \mathrm{db}=\mathrm{aph} \& \mathrm{AN}=25635325$.

82 Remnick pp. 463-464.

83 Thurston Clarke, The Last Campaign: Robert F. Kennedy and 82 Days that Inspired America (New York: Henry Holt and Company, 2008), p. 11, claims that Kennedy's picture reportedly hung in the offices of more Senators than any other Senator through history.

84 “What Does RFK's Assassination Have to Do with It?" May 23, 2008. [Online]. http://www.youtube.com/ watch?v=5vyFqmp4wzI.

85 "Clinton Kennedy Assassination Reference: Raises Bobby's Death to Explain Why She Stays in Race," The Huffington Post, May 23, 2008. [Online]. http://www.huffingtonpost.com/2008/05/23/ clinton-kennedyassassina_n_103319.html.

86 Jonathan Darman, "The Down and Out Tour," July 30, 2007. [Online]. http://www.newsweek. com/2007/07/29/the-down-and-out-tour.html; "John Edwards Set to Embark on Poverty Tour", July 13 2007. [Online]. http://www.npr.org/templates/story/ story.php?storyId=11924709. 
However, Edwards failed to attract public attention as effectively as Obama or Hillary Clinton.

Democrats continuing to assume Kennedy's vision of social justice and equality and thus infusing new partisan meaning into Kennedy's legacy has not changed his status in many Republican circles. However, in the public mind, he continues to be a non-partisan icon of conciliation, justice, and progress. The changes in Kennedy's political views, from tough on crime to healer of racial conflict, allow for Democrats and Republicans alike to choose the part of Kennedy's life which they find most convenient for their own political purposes. Robert F. Kennedy did not follow the narrow lines of traditional liberalism versus modern liberalism and proposed political solutions appealing to both parties. This ideological complexity mirrors the contradictions and struggles of American liberalism, and therefore Kennedy has the potential to remain a significant icon of liberalism. 